\title{
Telehealth as an Important Player in the Management of Hepatitis C Virus
}

\author{
Adeel Khoja ${ }^{1, * \mathbb{C}}$, Naureen Akber Ali ${ }^{2}$ and Anam Feroz ${ }^{3}$ \\ 1 Department of Medicine, The Aga Khan University, Stadium Road, P.O. Box 3500, Karachi 74800, Pakistan \\ 2 School of Nursing and Midwifery, The Aga Khan University, Stadium Road, P.O. Box 3500, \\ Karachi 74800, Pakistan; naureen.akberali@aku.edu \\ 3 Department of Community Health Sciences, The Aga Khan University, Stadium Road, P.O. Box 3500, \\ Karachi 74800, Pakistan; anam.feroz@aku.edu \\ * Correspondence: adeel.khoja@aku.edu
}

check for

updates

Citation: Khoja, A.; Ali, N.A.; Feroz, A. Telehealth as an Important Player in the Management of Hepatitis C Virus. Gastroenterol. Insights 2021, 12, 183-195. https://doi.org/10.3390/ gastroent12020016

Academic Editor: Paolo Muratori

Received: 1 March 2021

Accepted: 1 April 2021

Published: 3 April 2021

Publisher's Note: MDPI stays neutral with regard to jurisdictional claims in published maps and institutional affiliations.

Copyright: (c) 2021 by the authors. Licensee MDPI, Basel, Switzerland. This article is an open access article distributed under the terms and conditions of the Creative Commons Attribution (CC BY) license (https:// creativecommons.org/licenses/by/ $4.0 /)$.

\begin{abstract}
Background: Hepatitis C virus (HCV) is a global public health issue that can cause both acute and chronic liver diseases. There is a high risk of HCV burden, but limited access and cost remain a challenge for proper diagnosis and treatment. Leveraging eHealth technology may indicate a viable solution for the management of HCV patients. Objective: To review the literature regarding the role of eHealth, including telemedicine, in the management of HCV. Methods: Databases including PubMed, Google Scholar, Medline, Web of Science, and Science Direct were searched from 1 January 2008 to 30 June 2020 to identify different types of eHealth interventions used for the management of adult HCV patients. Our search also determined the role of telehealth for HCV patients in the current pandemic. Results: Four main categories emerged from this scoping review that includes improving treatment rates via utilizing telehealth services, satisfaction with the telehealth services, disease management, health promotion, and similarity between telehealth and traditional modalities. Conclusions: Current evidence suggests that telemedicine is a cost-effective and unique platform to improve patients' access to quality services that curb the increasing burden of this silent killer in developing countries. This modality can certainly be utilized in the current crisis to manage care for HCV patients efficiently.
\end{abstract}

Keywords: hepatitis C virus (HCV); telehealth; telemedicine

\section{Introduction}

Hepatitis $\mathrm{C}$ virus (HCV) is a blood-borne virus that can cause both acute and chronic liver disease depending upon the severity, ranging from mild to severe illnesses [1]. It is a global public health issue with a seroprevalence of around 1.6\% [2]. According to the World Health Organization Hepatitis report (WHO, 2017), nearly 71 million individuals are living with $\mathrm{HCV}$, which translates to a worldwide prevalence of $1.0 \%$ [1,2]. Moreover, it has been shown that the Eastern Mediterranean region has the highest HCV prevalence of $2.3 \%$, followed by European states at $1.5 \%$ [1], while, in other WHO regions, it ranges from $0.5 \%$ to $1.0 \%$ [1]. The burden of $\mathrm{HCV}$ is highest in developing countries: the greatest reported prevalence is in Egypt (22\%), followed by Pakistan (4.8\%) and China (3.2\%) [3].

Marginalized and remote communities mainly suffer from a huge burden of $\mathrm{HCV}$ as they face multifaceted barriers, including lack of awareness, dearth of healthcare professionals, unavailability of testing facilities, scarcity of resources, concerns about stigma or social isolation, and treatment costs [4,5]. This in turn hinders patients' access to healthcare services, which leads to poor diagnosis and management of HCV cases [6,7]. Furthermore, the use of unscreened blood products and unsterilized medical/dental equipment, such as needles and syringes, is a common medical practice that has been linked with the transmission of HCV infection [8]. In addition, other potential risk factors such as injectable drug use (sharing of needles), tattooing with reused needles, sexual contact with an infected 
person, and mother-to-child transmission also play an imperative role in the spread of HCV infection $[1,8,9]$.

Screening of $\mathrm{HCV}$ is vital and can be done by testing for anti-HCV antibodies with a serological test. A positive anti-HCV antibody test directs a person to an $\mathrm{HCV}$ ribonucleic acid (RNA) test (a diagnostic test) to confirm an active infection and to initiate timely treatment [1]. It is predicted that almost 1.4 million people who are not treated die each year due to HCV $[5,10]$. The WHO shared revised guidelines in 2018 and recommended treatment with pan-genotypic direct-acting anti-viral agents (DAAs) for all HCV patients that are 12 years old or older [1]. DAAs are effective as they can cure more than $95 \%$ of patients, ultimately resulting in reduced risk of HCV burden. Approximately 5 million patients were treated with DAAs by the end of 2017 [1]. Therefore, much effort is needed to reach the $\mathrm{WHO} 80 \% \mathrm{HCV}$ treatment target by 2030 , but limited access and cost remain a challenge for proper diagnosis and treatment [1].

Globally, HCV is a main cause of liver disease and it is predicted to be a significant cause of morbidity and mortality in the upcoming years [11]. A WHO report revealed that only 13.1 million, i.e., $19 \%$, were aware of their disease diagnosis. Therefore, there is dire need to improve access to care and treatment for patients with HCV. In order to bridge this gap, innovations are needed that can be incorporated into fragile healthcare systems. Leveraging eHealth technology, i.e., telehealth services, may indicate a viable solution for the management of $\mathrm{HCV}$, particularly in hard to reach, far-flung, and remote communities of the developing world which have no access to HCV healthcare specialists. There are many initiatives that have been taken to seek evidence regarding telehealth innovation for managing $\mathrm{HCV}$ patients. Telehealth has often been used interchangeably with telemedicine, which is defined as the delivery of healthcare services remotely by electronic means for "the diagnosis of, treatment, and prevention of disease and injuries, research and evaluation, education of healthcare providers" to improve health [12].

Studies have shown that patients managed via telehealth during the entire course of the treatment showed an increased uptake of HCV drug therapy. This has subsequently led to higher sustained virological response (SVR) rates as compared to patients treated with the traditional model of HCV care, i.e., face-to-face consultations [13,14]. This technology was also found to be an effective and feasible tool for timely screening, diagnosis and treatment of $\mathrm{HCV}$, particularly in underserved populations that are subject to multiple barriers like poverty and a lack of medical experts and primary healthcare centers [15].

In order to accurately gauge the abovementioned research gap, we performed a thorough literature search that provided valuable insights into the application of telehealth to treat HCV patients and also shed light on the use of telehealth among HCV patients in the current pandemic era.

\section{Methods}

We used the methodological framework outlined by Levac and his colleagues, which was based on previous work by Arksey and O'Malley $[16,17]$. This systematically directed the steps, which included identifying the relevant studies according to the research aim, selecting appropriate studies and then summarizing and reporting the findings. This search guided the role of telehealth in chronic liver disease such as HCV and can also guide future research. We carried out an electronic literature search on a target group of hepatitis C patients who were managed via telehealth. Studies were selected based on the following criteria: participants (populations), intervention (exposure), outcome(s) of interest, study design, and time duration. We included studies involving adult $\mathrm{HCV}$ patients (regardless of gender), whereas adults with other severe morbidities (e.g., HIV, carcinoma, and psychiatric illness) were not eligible. Studies that utilized telehealth for the management of $\mathrm{HCV}$ patients were incorporated into this paper, while studies that utilized telehealth services for the capacity building of healthcare professionals and for the management of other chronic ailments were excluded. We included studies demonstrating outcomes related to the utilization of telehealth services for the management (screening, 
diagnosis, and treatment) of HCV and expanded our search strategy to identify the role of this innovative modality in the current pandemic. Original studies (experimental and observational) including cross-sectional, case-control, cohort, randomized controlled trials, quasi-experimental studies, clinical control trials, qualitative studies, mixed methods for which full-text articles could be retrieved were mainly used. On the contrary, case studies, case series, systematic reviews, protocols, commentaries, editorials, letters to the editor, unpublished articles (gray literature), symposium proceedings, conference abstracts, and irretrievable documents were not included in this review. All studies published in English, from 1 January 2008 to 30 June 2020, were examined. The studies included in this literature review are presented in Table 1.

\subsection{Information Sources and Search Strategy}

Studies incorporated in this literature review were rigorously searched by using several electronic databases (from January 2000 onwards): Medline/PubMed, Web of Science, Science Direct, and Google Scholar. We performed hand-searching of the reference lists of the included studies, relevant reviews, or other relevant documents. The literature search was designed and conducted by the review team. The search terms were grouped into the following categories of interest: population (e.g., adult HCV patients), epidemiological studies (e.g., quantitative, qualitative, and mixed methods studies), outcomes (e.g., management of HCV patients via telehealth), and duration (e.g., studies included from January 2000 onwards). Additionally, indexed keywords in the medical subject headings (MeSH) were used to ensure uniform search terms.

\subsection{Screening and Selection of Studies}

All articles identified from the literature search were uploaded into the EndNote referencing software. Records were screened by two reviewers (AK and NA) independently. A pre-defined screening tool was designed, and a pilot testing was conducted. The selected studies were first screened by titles, then by abstract, and finally by full text to gradually exclude the studies that did not meet the eligibility criteria. Initially, we found a total of 1066 studies from the abovementioned databases. After removing duplicates, 58 were screened based on their titles. Subsequently, in the title screening phase, 38 studies were screened in accordance with the abstracts, removing 20 studies in the process. During the screening of abstracts, full-text articles of 26 studies were assessed as per the eligibility criteria, removing 11 studies in the same process. Later, a single study was found from cross-referencing which was also included. As a result of the whole screening process, we included 16 studies for the purpose of this review as per our pre-defined eligibility criteria [13-15,18-30]. The entire process of study screening and selection is exemplified in the PRISMA flow diagram in Figure 1.

\subsection{Data Collection Process}

Data were extracted into a customized sheet in Excel that was completed by two independent reviewers (NA, AK) for the eligible studies. The data extraction table was completed by two reviewers to confirm that all the main findings were included. An extraction table is provided in Table 1. The form included primary author, year of publication, study title, country of study, objective, study design, study population, and important findings. Any inconsistencies between the two reviewers in the entire process were discussed and the issue was resolved through mutual consensus. 
Table 1. Extraction table.

\begin{tabular}{|c|c|c|c|c|c|c|c|}
\hline $\begin{array}{c}\text { Author and } \\
\text { Year }\end{array}$ & Study Title & $\begin{array}{l}\text { Study } \\
\text { Design }\end{array}$ & Country & $\begin{array}{c}\text { Mode of } \\
\text { Intervention }\end{array}$ & $\begin{array}{c}\text { Target } \\
\text { Population }\end{array}$ & Study Aim & Important Findings \\
\hline $\begin{array}{l}\text { 1. Morey } \\
\text { et al., } 2019\end{array}$ & $\begin{array}{l}\text { Increased diagnosis and } \\
\text { treatment of hepatitis } C \\
\text { in prison by universal } \\
\text { offer of testing and use } \\
\text { of telemedicine }\end{array}$ & $\begin{array}{l}\text { Cross- } \\
\text { sectional }\end{array}$ & $\begin{array}{l}\text { North East } \\
\text { England }\end{array}$ & $\begin{array}{c}\text { Telemedicine clinics } \\
\text { for hepatitis } \mathrm{C} \text { virus } \\
\text { (HCV) treatment }\end{array}$ & $\begin{array}{l}\text { Prisoners with } \\
\text { hep C }\end{array}$ & $\begin{array}{l}\text { To assess the implementation of: } \\
\text { - Telemedicine clinics (TCs) to increase } \\
\text { HCV treatment rates } \\
\text { - A universal offer of blood-borne } \\
\text { virus testing using dry blood spot testing } \\
\text { for prisoners at reception to increase } \\
\text { diagnosis }\end{array}$ & $\begin{array}{l}\text { - Telemedicine clinics can substantially increase } \\
\text { rates of testing, diagnosis, and treatment of HCV in } \\
\text { this high-prevalence population } \\
\text { - A universal offer of blood-borne virus testing to } \\
\text { prisoners presenting at Her Majesty's Prison } \\
\text { reception coupled with linkage to specialist care via } \\
\text { telemedicine } \\
\text { - Overall, satisfaction with the TC among the } \\
\text { prisoners was very high ( } 80 \% \text { good or excellent). }\end{array}$ \\
\hline $\begin{array}{l}\text { 2. Mohsen } \\
\text { et al., } 2019\end{array}$ & $\begin{array}{l}\text { Hepatitis } C \text { treatment } \\
\text { for difficult to access } \\
\text { populations: Can } \\
\text { telemetering (as distinct } \\
\text { from telemedicine) } \\
\text { help? }\end{array}$ & $\begin{array}{l}\text { Retrospective } \\
\text { cohort study }\end{array}$ & Australia & $\begin{array}{l}\text { Telementoring } \\
\text { program }\end{array}$ & $\begin{array}{l}\text { Treatment of } \\
\text { difficult to } \\
\text { access } \\
\text { populations } \\
\text { (DTAPs) with } \\
\text { hep C }\end{array}$ & $\begin{array}{l}\text { To determine: } \\
\text { - Can the Project ECHO (PE) } \\
\text { (Extension for Community Healthcare } \\
\text { Outcomes) model support primary care } \\
\text { clinicians treating HCV and to compare } \\
\text { cohort of PE patients with those in a } \\
\text { tertiary liver clinic }\end{array}$ & $\begin{array}{l}\text { - PE is an effective model to support primary } \\
\text { healthcare providers treating HCV in difficult to } \\
\text { access populations } \\
\text { - Similar rates of treatment uptake and sustained } \\
\text { virological response were noted as compared to } \\
\text { patients in tertiary liver clinic }\end{array}$ \\
\hline $\begin{array}{l}\text { 3. Cooper } \\
\text { et al., } 2018\end{array}$ & $\begin{array}{l}\text { Direct-Acting Antiviral } \\
\text { Therapy Outcomes in } \\
\text { Canadian Chronic } \\
\text { Hepatitis C } \\
\text { Telemedicine Patients }\end{array}$ & Cohort & Canada & Telemedicine (TM) & HCV patients & $\begin{array}{l}\text { To compare: } \\
\text { • Patient characteristics, fibrosis } \\
\text { work-up, and antiviral treatment } \\
\text { outcomes in TM and non-TM patients }\end{array}$ & $\begin{array}{l}\text { - Our TM program engages and retains a } \\
\text { population that faces many barriers to effective HCV } \\
\text { treatment } \\
\text { - TM patients initiated HCV therapy and achieved } \\
\text { high SVR rates comparable to those obtained using } \\
\text { traditional models of care }\end{array}$ \\
\hline $\begin{array}{l}\text { 4. Yoo et al., } \\
2017\end{array}$ & $\begin{array}{l}\text { The Role of eHealth in } \\
\text { Optimizing } \\
\text { Task-Shifting in the } \\
\text { Delivery of Antiviral } \\
\text { Therapy for Chronic } \\
\text { Hepatitis C }\end{array}$ & $\begin{array}{l}\text { Retrospective } \\
\text { analysis }\end{array}$ & California & eHealth & $\begin{array}{l}\text { Patients } \\
\text { withchronic } \\
\text { hepatitis } C \\
\text { virus }(\mathrm{HCV}) \\
\text { infection }\end{array}$ & $\begin{array}{l}\text { To assess: } \\
\text { - Impact of eHealth on task-shifting for } \\
\text { HCV patients receiving treatment with } \\
\text { direct-acting antiviral (DAA) agents }\end{array}$ & $\begin{array}{l}\text { - Positive impact of eHealth in optimizing } \\
\text { task-shifting for direct-acting antivirals (DAAs) in } \\
\text { HCV-infected patients in underserved outreach } \\
\text { clinics } \\
\text { - Secondary improvement in access and capacity of } \\
\text { clinic was also noted }\end{array}$ \\
\hline $\begin{array}{l}\text { 5. Beste et al., } \\
2017\end{array}$ & $\begin{array}{l}\text { Telemedicine Specialty } \\
\text { Support Promotes } \\
\text { Hepatitis C Treatment } \\
\text { by Primary Care } \\
\text { Providers in the } \\
\text { Department of Veterans } \\
\text { Affairs }\end{array}$ & Cohort study & US & $\begin{array}{c}\text { Video } \\
\text { conferencing-based } \\
\text { specialist support }\end{array}$ & $\begin{array}{l}\text { Patients } \\
\text { withchronic } \\
\text { hepatitis C } \\
\text { infection }\end{array}$ & $\begin{array}{l}\text { To assess: } \\
\text { - Whether primary care provider } \\
\text { participation in Veterans Affairs } \\
\text { Extension for Community Health } \\
\text { Outcomes (VA-ECHO) was associated } \\
\text { with hepatitis } \mathrm{C} \text { treatment and sustained } \\
\text { virological response }\end{array}$ & $\begin{array}{l}\text { - Veterans Affairs Extension for Community Health } \\
\text { Outcomes (VA-ECHO) was positively associated } \\
\text { with hepatitis C treatment initiated by primary care } \\
\text { providers, without differences in sustained } \\
\text { virological response }\end{array}$ \\
\hline $\begin{array}{l}\text { 6. Keogh } \\
\text { et al., } 2016\end{array}$ & $\begin{array}{l}\text { Use of tele-health to } \\
\text { treat and manage } \\
\text { chronic viral hepatitis in } \\
\text { regional Queensland }\end{array}$ & $\begin{array}{c}\text { Retrospective } \\
\text { audit }\end{array}$ & Australia & Telehealth & $\begin{array}{l}\text { Chronic viral } \\
\text { hepatitis } \\
\text { patients }\end{array}$ & $\begin{array}{l}\text { To determine: } \\
\text { - Factors contributing to success of } \\
\text { telehealth service and identification of } \\
\text { ongoing challenges to the service model }\end{array}$ & $\begin{array}{l}\text { - Our integrated team approach to delivering } \\
\text { telehealth services is feasible for regional patients } \\
\text { with complex medical needs } \\
\text { - Continued expansion of these services is } \\
\text { contingent on more flexible delivery networks and } \\
\text { better access to videoconferencing infrastructure } \\
\text { within general practice settings and at-home settings }\end{array}$ \\
\hline
\end{tabular}


Table 1. Cont.

\begin{tabular}{|c|c|c|c|c|c|c|c|}
\hline $\begin{array}{c}\text { Author and } \\
\text { Year }\end{array}$ & Study Title & $\begin{array}{l}\text { Study } \\
\text { Design }\end{array}$ & Country & $\begin{array}{c}\text { Mode of } \\
\text { Intervention }\end{array}$ & $\begin{array}{c}\text { Target } \\
\text { Population }\end{array}$ & Study Aim & Important Findings \\
\hline $\begin{array}{l}\text { 7. Chen et al., } \\
2014\end{array}$ & $\begin{array}{l}\text { Translational Research } \\
\text { of Tele-care for the } \\
\text { Treatment of Hepatitis } \\
\text { C }\end{array}$ & Cohort & Taiwan & Telecare program & $\begin{array}{l}\text { Chronic viral } \\
\text { hepatitis } \\
\text { patients }\end{array}$ & $\begin{array}{l}\text { To investigate: } \\
\text { - Effectiveness of telecare for the } \\
\text { treatment of chronic hepatitis }\end{array}$ & $\begin{array}{l}\text { - Telecare system with healthcare communication } \\
\text { center model was significant in reducing dropout } \\
\text { rate and was more effective with easy access }\end{array}$ \\
\hline $\begin{array}{l}\text { 8. You et al., } \\
2014\end{array}$ & $\begin{array}{l}\text { A pharmacist-managed } \\
\text { telemedicine clinic for } \\
\text { hepatitis C care: A } \\
\text { descriptive analysis }\end{array}$ & $\begin{array}{l}\text { Cross- } \\
\text { sectional }\end{array}$ & USA & Telemedicine clinic & $\begin{array}{l}\text { Hepatitis C } \\
\text { patients }\end{array}$ & $\begin{array}{l}\text { To assess: } \\
\text { - Patients' perception of a hepatitis C } \\
\text { telemedicine clinic in comparison with } \\
\text { visits to a clinic in West Los Angeles }\end{array}$ & $\begin{array}{l}\text { The use of telemedicine increased opportunities } \\
\text { for patients living in remote areas to receive care for } \\
\text { hepatitis } C \text { management }\end{array}$ \\
\hline $\begin{array}{l}\text { 9. Rossaro } \\
\text { et al., } 2013\end{array}$ & $\begin{array}{l}\text { Clinical Outcomes of } \\
\text { Hepatitis C Treated } \\
\text { with Pegylated } \\
\text { Interferon and Ribavirin } \\
\text { via Telemedicine } \\
\text { Consultation in } \\
\text { Northern California }\end{array}$ & $\begin{array}{l}\text { Retrospective } \\
\text { analysis }\end{array}$ & US & $\begin{array}{l}\text { Telemedicine } \\
\text { consultation }\end{array}$ & $\begin{array}{l}\text { Hepatitis C } \\
\text { patients }\end{array}$ & $\begin{array}{l}\text { To determine: } \\
\text { - Treatment response and side effect } \\
\text { profiles among HCV patients treated } \\
\text { with pegylated interferon and ribavirin } \\
\text { via telemedicine consultation in different } \\
\text { rural locations in Northern California } \\
\text { compared with patients treated at } \\
\text { traditional hepatology office visits }\end{array}$ & $\begin{array}{l}\text { - The two groups had equivalent sustained } \\
\text { virological responses (SVRs). For the TM group, } \\
\text { therapy completion was superior and incidence of } \\
\text { anemia was lower } \\
\text { - Patients with HCV can be safely and effectively } \\
\text { treated via telemedicine }\end{array}$ \\
\hline $\begin{array}{l}\text { 10. Nazareth } \\
\text { et al., } 2013\end{array}$ & $\begin{array}{l}\text { Successful treatment of } \\
\text { patients with hepatitis } \\
\text { C in rural and remote } \\
\text { Western Australia via } \\
\text { tele-health }\end{array}$ & Cohort & Australia & Telehealth & $\begin{array}{l}\text { Hepatitis C } \\
\text { patients }\end{array}$ & $\begin{array}{l}\text { To assess: } \\
\text { f Whether telehealth can provide a } \\
\text { feasible mode of healthcare delivery to } \\
\text { patients with HCV }\end{array}$ & $\begin{array}{l}\text { - The study confirmed that telehealth is an effective } \\
\text { option for the treatment of hepatitis } C \text { in rural and } \\
\text { remote areas } \\
\text { - Treatment through telehealth was found to be } \\
\text { non-inferior to face-to-face clinics. Total of } 35 \\
\text { telehealth patients completed a satisfaction } \\
\text { questionnaire and most indicated that they were } \\
\text { happy with the program and would participate again } \\
\text { in the future }\end{array}$ \\
\hline $\begin{array}{l}\text { 11. Lloyd } \\
\text { et al., } 2013\end{array}$ & $\begin{array}{l}\text { Safety and Effectiveness } \\
\text { of a Nurse-Led } \\
\text { Outreach Program for } \\
\text { Assessment and } \\
\text { Treatment of Chronic } \\
\text { Hepatitis C in the } \\
\text { Custodial Setting }\end{array}$ & $\begin{array}{l}\text { Mixed } \\
\text { methods }\end{array}$ & Australia & Telemedicine & $\begin{array}{l}\text { Inmates } \\
\text { withchronic } \\
\text { HCV }\end{array}$ & $\begin{array}{l}\text { To illustrate: } \\
\text { - Feasibility, efficacy, and safety of } \\
\text { nurse-led and specialist-supported } \\
\text { assessment and treatment of inmates } \\
\text { with chronic HCV utilizing telemedicine }\end{array}$ & $\begin{array}{l}\text { - This nurse-led and specialist-supported } \\
\text { assessment and treatment model via utilizing } \\
\text { telemedicine with chronic HCV offered potential to } \\
\text { substantively increase treatment uptake and reduce } \\
\text { the burden of disease }\end{array}$ \\
\hline $\begin{array}{l}\text { 12. Rossaro } \\
\text { et al., } 2008\end{array}$ & $\begin{array}{l}\text { The Evaluation of } \\
\text { Patients with Hepatitis } \\
\text { C Living in Rural } \\
\text { California via } \\
\text { Telemedicine }\end{array}$ & $\begin{array}{l}\text { Retrospective } \\
\text { analysis }\end{array}$ & US & Telemedicine & $\begin{array}{l}\text { Patients with } \\
\text { hepatitis C }\end{array}$ & $\begin{array}{l}\text { To determine: } \\
\text { - Whether a hepatology telemedicine } \\
\text { clinic will increase access to specialty } \\
\text { care especially among those with } \\
\text { advanced disease living in an } \\
\text { underserved community }\end{array}$ & $\begin{array}{l}\text { - Telemedicine was an effective tool for identifying } \\
\text { and treating patients with hepatitis } C \text { who live in } \\
\text { rural communities }\end{array}$ \\
\hline
\end{tabular}


Table 1. Cont.

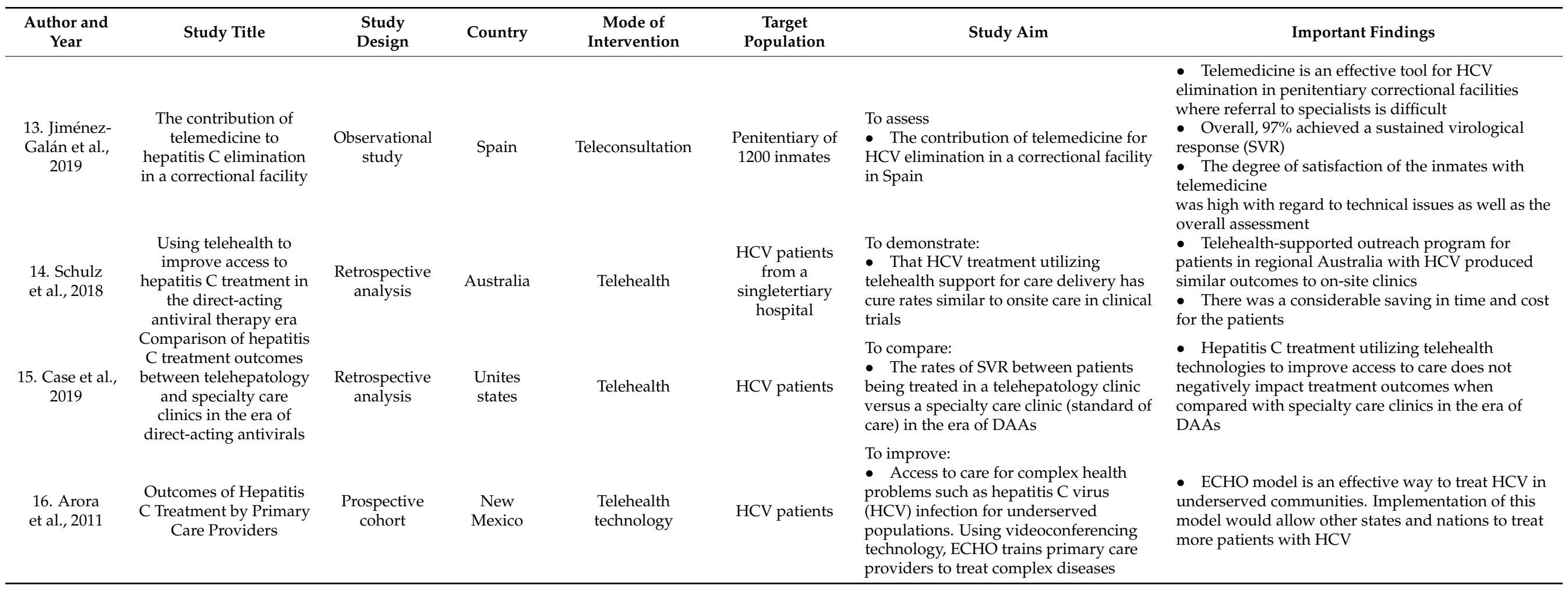



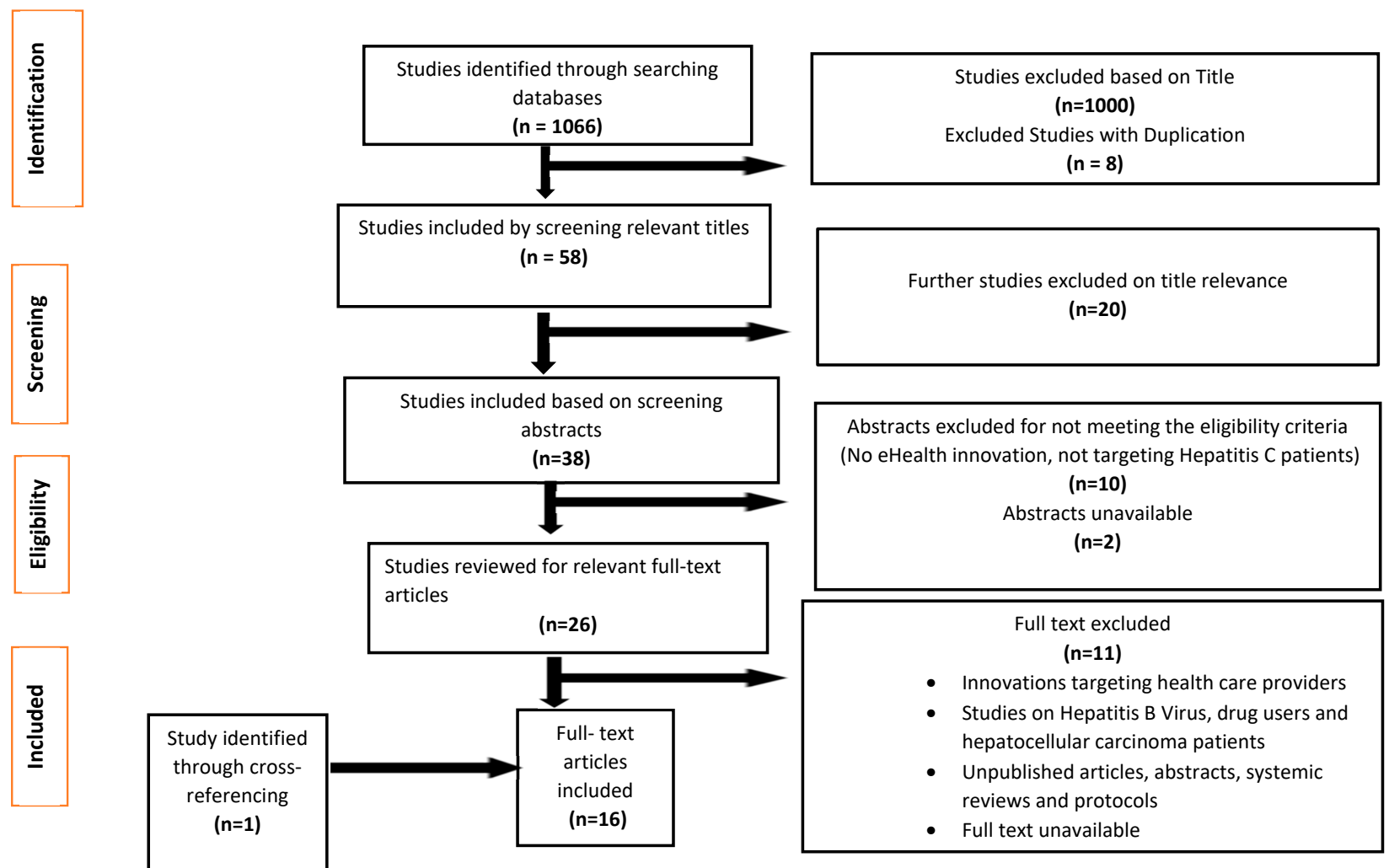

Figure 1. PRISMA Flow Diagram—Searching Databases for this review.

\subsection{Assessment of Study Quality}

The quality of the included studies was evaluated by standardized quality assessment tool, known as the mixed methods appraisal tool (MMAT). This tool was used to evaluate the methodological quality of all non-randomized studies. Overall, most studies included in this review were of good quality, indicating the significance of the methodological rigor. The purpose was to examine and gain insight into the rigor of existing research in this field. Two reviewers (NA, AK) independently assessed the quality of the included studies. In case of disagreement between the two, a third reviewer (AF) was consulted. Data on quality appraisal are provided in Table 2 for all the included studies. 
Table 2. Quality appraisal. Result of quality appraisal, the mixed methods appraisal tool (MMAT).

\begin{tabular}{|c|c|c|c|c|c|}
\hline \multirow[b]{2}{*}{$\begin{array}{c}\text { Quantitative } \\
\text { Non-Randomized Studies }\end{array}$} & \multicolumn{5}{|c|}{ Quality Assessment Components Using MMAT } \\
\hline & $\begin{array}{c}\text { Are Participants Recruited } \\
\text { in a Way That Minimizes } \\
\text { Selection Bias? }\end{array}$ & $\begin{array}{c}\text { Are Measurements } \\
\text { Appropriate } \\
\text { Regarding the Exposure or } \\
\text { Intervention and Outcomes? }\end{array}$ & $\begin{array}{l}\text { In the Groups Being Compared, are } \\
\text { the Participants } \\
\text { Comparable, or Do Researchers Take } \\
\text { into Account? }\end{array}$ & $\begin{array}{c}\text { Are There Complete Outcome Data } \\
\text { ( } 80 \% \text { or Above), an Acceptable } \\
\text { Response Rate (60\% or Above), or An } \\
\text { Acceptable } \\
\text { Follow-Up Rate for Cohort Studies? }\end{array}$ & Total \\
\hline Morey et al., 2019 & 0 & 1 & 1 & 1 & 3 \\
\hline Mohsen et al., 2019 & 1 & 1 & 1 & 1 & 4 \\
\hline Cooper et al., 2018 & 1 & 1 & 1 & 1 & 4 \\
\hline Yoo et al., 2017 & 0 & 1 & 1 & 1 & 3 \\
\hline Beste et al., 2017 & 1 & 1 & 1 & 1 & 4 \\
\hline Keogh et al., 2016 & 1 & 1 & 1 & 1 & 4 \\
\hline Chen et al., 2014 & 1 & 1 & 1 & 1 & 4 \\
\hline You et al., 2014 & 1 & 1 & 1 & 0 & 3 \\
\hline Rossaro et al., 2013 & 1 & 1 & 1 & 1 & 4 \\
\hline Nazareth et al., 2013 & 1 & 1 & 1 & 1 & 4 \\
\hline Rossaro et al., 2008 & 1 & 1 & 1 & 0 & 3 \\
\hline Jiménez-Galán et al., 2019 & 1 & 1 & 1 & 1 & 4 \\
\hline Schulz et al., 2018 & 1 & 1 & 1 & 1 & 4 \\
\hline Arora et al., 2011 & 1 & 1 & 1 & 1 & 4 \\
\hline \multicolumn{6}{|l|}{ Total $=15$} \\
\hline Mixed method Studies & $\begin{array}{c}\text { Are the Sources of Data } \\
\text { Relevant to Research } \\
\text { Question? }\end{array}$ & $\begin{array}{l}\text { Is the Data Analyzing } \\
\text { Process Relevant to Address } \\
\text { Research Question? }\end{array}$ & $\begin{array}{l}\text { Is Appropriate Consideration Given } \\
\text { to How Findings Relate to Context? }\end{array}$ & $\begin{array}{l}\text { Is Appropriate Consideration Given } \\
\text { to How Findings Relate to } \\
\text { Researchers' Influence? } \\
\text { (REFLEXIVITY) }\end{array}$ & Total \\
\hline $\begin{array}{c}\text { Lloyd et al., } 2013 \\
\text { Total = } 1\end{array}$ & 1 & 1 & 1 & 1 & 4 \\
\hline
\end{tabular}




\section{Results}

We included data from 16 selected studies that have utilized telehealth as an innovative mode of communication for the management of hepatitis $C$ virus patients. Out of sixteen studies, ten studies were retrospective cohort studies [13-15,19,20,22,23,26,28,29], three were prospective cohort studies $[18,24,30]$, one was a mixed methods study (both qualitative and quantitative components) [21] and the remaining two were observationaldescriptive studies $[25,27]$. The final selected studies were divided into four main categories which included improving treatment rates via utilizing telehealth services, satisfaction with telehealth services, disease management and health promotion, and similarity between telehealth and traditional modalities.

\subsection{Improving Treatment Rates via Utilizing Telehealth Services}

The studies classified under this domain have shown that utilization of telehealth services has significantly improved treatment rates among HCV patients $[14,18,22,24]$. A cohort study was done in Taiwan to examine the effectiveness of "telecare" for the treatment of hepatitis C patients. A total of 298 patients randomly chose to be part of the following two groups: in group 1 , nurse consultation was offered at an outpatient clinic, while in group 2, a $24 \mathrm{~h}$ telephone consultation service was offered through a health communication center. All patients were managed with standard therapy and followed up for 72 weeks. Patience compliance in group 1 was noted to be $88 \%$, while it was $94.6 \%$ in group 2 . In addition, the dropout rates were $12 \%$ and $5.4 \%$ in group 1 and group 2 , respectively. Thus, it was found that this innovation has increased treatment efficacy by improving compliance rate and reducing dropout among the telehealth group as compared to the standard therapy [18]. A cohort database study on hepatitis $C$ identified that half as many telemedicine (TM) patients commenced antiviral therapy than non-telemedicine patients $(27.4 \%$ versus $53.8 \%, p$-value $<0.001)$ [14]. This study concluded that the telemedicine program successfully motivated and retained a vulnerable population that suffered from multiple challenges during their HCV treatment [14]. Hence, telemedicine has tremendous potential to enhance patients' drug adherence rates as compared to traditional modes of treatment. A study conducted on prisoners in northeast England revealed that $83 \%$ of the prisoners attended telemedicine services, $71 \%$ initiated an antiviral drug regimen, and $100 \%$ with known outcome attained sustained virological response. Thus, telemedicine clinics can significantly increase management (testing, diagnosis, and treatment) of HCV among prisoners [22]. Another study showed that 6431 patients who were under primary care providers participated in Veterans Affairs Extension for Community Health Outcomes (VAECHO) telemedicine sessions, whereas 32,322 patients did not have any video conferencing (unexposed group). The exposed group had considerably higher rates of antiviral drug therapy as compared to the unexposed group (hazard ratio: 1.20 ; $95 \%$ CI: 1.10 to 1.32 ; $p$-value $<0.01)$. The rate of antiviral treatment initiated by the primary care provider was $21.4 \%$ among VA-ECHO teleconference group participants compared to $2.5 \%$ among unexposed group participants ( $p$-value $<0.01$ ) [24]. Thus, the telemedicine program was strongly associated with a higher rate of hepatitis $C$ treatment initiation by primary care providers without raising the load of in-person specialty services.

\subsection{Satisfaction with Telehealth Services}

Different studies $[22,25-27,29]$ have suggested that telehealth has a potential to enhance user satisfaction that ultimately increases patients' engagement with the treatment. Overall, the satisfaction level highlighted in studies ranged from $70 \%$ to $80 \%$ [22,25-27]. These studies also put forth the feasibility of services in terms of saving patients' time and cost $[26,29]$. This novel technology has enhanced the treatment opportunities for individuals suffering from hepatitis $C$, residing in hard to reach and underprivileged areas [25]. Moreover, patients preferred telemedicine services over the traditional mode of clinic visits due to the high level of privacy and confidentiality, along with the quality of care they received [29]. Additionally, the majority of the patients shared their readiness to utilize 
telehealth services in the future, along with recommending this innovation to their families and friends $[25,26]$.

\subsection{Disease Management and Health Promotion}

Health promotion and disease prevention are fundamental to manage disease and control HCV-related outbreaks in a timely manner. Utilizing telehealth services enabled earlier access to healthcare services that can inhibit disease complications at a rapid rate. Studies showed that the feasibility, efficacy, and safety of telemedicine have resulted in an increased uptake of HCV treatments among patients, which contributed towards reducing the disease burden, particularly in remote and underprivileged areas that suffer additional challenges such as poverty and fewer medical experts, centers, and other basic resources [15,21,23,28]. A study done by Keogh et al. in 2016 also showed a positive impact, as there was a more than four-fold increment in consultations, which reflects that telehealth increased patient engagement, decreased loss to follow-up, and reduced delay in seeking treatment among HCV patients [19]. A retrospective analysis identified that almost 95\% of patients did not require a follow-up visit due to optimization of task-shifting via utilizing eHealth clinics [13]. A cohort of patients undergoing telemedicine consultations at the Peach Tree Clinic in rural Northern California found that $37 \%$ had cirrhosis and $64 \%$ of them had never received any treatment or undergone any treatment regimen. This study indicated telemedicine as an innovative tool for the timely screening and treatment of hepatitis $C$ patients, especially for rural communities that suffer from multiple barriers, including higher poverty rates and fewer medical experts, and resources [15]. Similarly, another study also highlighted that 108 (28\%) patients initiated treatment and 85 (79\%) were triaged for professional assessment through telemedicine [21]. This advancement in technology offered direct and secure communication among healthcare providers and directed earlier and proper treatment among patients by healthcare experts $[13,15]$. A retrospective cohort study done by Mohsen et al. in 2019 also assessed if Project ECHO (PE) supported on-site clinicians treating HCV patients and compared the cohort of PE patients with tertiary liver clinic (TLC) patients. A total of 100 PE patients were discussed at a weekly teleconference scheduled for one to two hours and they were compared with 100 newly consulted HCV patients at the TLC via videoconferencing using the "hub and spoke" model. In both groups, almost $98 \%$ of the patients with virological follow-up who finished treatment and continued follow-up had a confirmed SVR. This helped in building professional expertise via modern technology rather than the traditional healthcare model, thus empowering healthcare professionals and strengthening the healthcare system [23]. Further, it was estimated that $86,720 \mathrm{~km}$ of patient travel were saved via using the telemedicine service [28]. Therefore, the expansion of a team-based telemedicine model can play a pivotal role in the successful utilization of a service and curb the transmission of hepatitis C virus [19].

\subsection{Similarity between the Two Modalities, i.e., Telemedicine vs. Traditional Method}

It was also evident from studies that no difference existed between telemedicine and traditional modes of treatment. The 2013 article by Rossaro et al. assessed treatment responses among $80 \mathrm{HCV}$ patients treated with pegylated interferon and ribavirin through telemedicine (TM) consultation $(n=40)$ as compared to patients treated in hepatology clinics (HCs, $n=40)$. It was observed that patients in the TM group had more visits per week of therapy as compared to those in the HC group (TM: 0.61 vs. HC: $0.07 ; p<0.001$ ). However, no difference was observed in response to therapy (TM: 55\% vs. HC: 43\%; $p$-value $=0.36$ ) [20]. Other studies compared the rates of SVR among HCV patients treated with telehealth as compared to gastroenterology clinics or face-to-face clinics $[26,29,30]$. It was noted that there was no significant difference in the sustained virologic response rate between the telehealth and face-to-face groups (73\% versus 54\%, respectively) [26]. Similarly, other studies also showed that SVR rates were insignificant between the two 
treatment modalities [29,30]. Telehealth technologies have improved access to care for hepatitis C patients, particularly in remote areas $[26,29,30]$.

\section{Discussion}

This review synthesized evidence on the use of telehealth technology in healthcare systems to manage patients with $\mathrm{HCV}$. Telehealth can possibly reach the boundaries of patients by crossing the barriers of proximity [31]. The introduction of this novel modality in healthcare can bring ease in terms of the screening, diagnosis, and treatment of populations suffering from HCV. The role of telehealth identified in this review mainly focused on improving treatment rates via utilizing telehealth services, satisfaction with the telemedicine services, disease management and health promotion, and similarity between the two modalities.

Overall, the studies identified were done in the developed world but mostly targeted the HCV population residing in remote regions. A previous systematic review also recognized telehealth as the potential option for healthcare providers in terms of expanding their services in far-flung or hard to reach areas. This review also highlighted that telehealth provided direct linkage of patients' with expert healthcare providers that enabled the delivery of competent care and enhanced patients' expectations of the services [31].

Based on our analysis, most of the studies showed an improvement in treatment rates via utilizing telemedicine services compared to the usual mode of care $[14,18,22,24]$. Various studies suggested that HCV patients receiving telehealthcare attained similar sustained virologic response (SVR) rates as compared to the traditional mode of care $[20,26,29,30]$. A recent systematic review done by Gijsel et al. (2018) found a telehealth-supported program to be an effective medium in achieving similar cure rates for HCV patients as compared to face-to-face modes, particularly in rural areas where there is inadequate access to specialized care [32].

Telehealth technology is an acceptable modality among patients with chronic diseases [31]. Studies identified in this review showed that patients suffering from HCV preferred remote teleconsultation services because this high-quality service not only increased patients' access to and connection with specialized care but the ease of use saved patients' time and reduced their travel time and cost, which in turn helped to improve their outcomes and increased their acceptability and satisfaction level with the service [22,25-27,29].

Different studies also pointed out that telemedicine can contribute towards reducing the disease burden by providing timely treatment and care through healthcare professionals, preventing disease progression $[13,15,19,21,23,28]$. Previous studies also revealed that a lack of optimal care for $\mathrm{HCV}$ patients has been recognized as a fundamental barrier to initiating antiviral treatment $[20,33]$. Thus, the telehealth innovation allows prompt evaluation and treatment of individuals infected with HCV.

As with most reviews in the evolving field of telehealth and $\mathrm{HCV}$, this review is limited by the difficulty in analyzing types of telehealth interventions across the included studies. In addition, fear of HCV-related stigma and discrimination, which hinders patients' access to healthcare settings/centers to initiate their treatment in a timely manner, is also not discussed [34]. Furthermore, no evidence exists on the role of telehealth utilization in developing countries, including Pakistan, where the prevalence rate is increasing at an alarming rate. Therefore, a more comprehensive understanding of the role of telehealth use for improving SVR rates among marginalized populations from developing countries is needed to refine the existing work with a larger body of evidence among diverse populations. Additionally, the role of governments is also required to incorporate this innovation into existing healthcare systems, particularly in the current pandemic where routine services for HCV patients are hampered. This call for policymakers to help legislation to catch up with this innovation by permitting further means of reimbursement for this modality will subsequently reduce the infection rate and improve public health at large. This review also recommends more clarification regarding the challenges of using this modality, including 
privacy and confidentiality of patients, level of data security, and technological glitches that hamper the utilization of telehealth in managing HCV cases.

\section{Conclusions}

In a nutshell, the current evidence from the literature suggests that telemedicine is an effective and unique platform for the management of HCV patients, specifically those residing in remote and far-flung communities. This innovation improves patients' access to quality services, including distant care delivery and access to experts/specialists, thus enabling effective utilization of cost and time. Furthermore, with the current lockdown and social distancing rules, this innovation is highly significant to avoid delay in treatment. Integration of telehealth services in the existing healthcare models of both developed and developing countries is essential for early treatment of $\mathrm{HCV}$. This in turn will reduce the existing HCV burden globally and play a key role in achieving the Sustainable Development Goals for HCV by the year 2030.

Author Contributions: N.A.A. and A.K. conceptualized the research idea. A.K. and N.A.A. screened and selected the studies. N.A.A., A.K. and A.F. analyzed and interpreted the data. N.A.A. wrote the first draft of the manuscript. N.A.A., A.K. and A.F. gave critical feedback. All authors have read and agreed to the published version of the manuscript.

Funding: This research did not receive any specific grant from funding agencies in the public, commercial, or not-for-profit sectors.

Institutional Review Board Statement: Not applicable.

Informed Consent Statement: Not applicable.

Conflicts of Interest: The authors declare no conflict of interest.

\section{References}

1. World Health Organization (WHO, 2017). Hepatitis C, Key Facts. Available online: https://www.who.int/news-room/factsheets / detail/hepatitis-c (accessed on 30 May 2020).

2. Gower, E.; Estes, C.; Blach, S.; Razavi-Shearer, K.; Razavi, H. Global epidemiology and genotype distribution of the hepatitis C virus infection. J. Hepatol. 2014, 61, S45-S57. [CrossRef] [PubMed]

3. Ford, N.; Kirby, C.; Singh, K.; Mills, E.J.; Cooke, G.; Kamarulzaman, A.; Ducros, P. Chronic hepatitis C treatment outcomes in lowand middle-income countries: A systematic review and meta-analysis. Bull. World Health Organ. 2012, 90, 540-550. [CrossRef] [PubMed]

4. Nishtar, S. The Gateway Paper. Health Systems in Pakistan-a Way Forward; Pakistan Health Policy Forum: Islamabad, Pakistan, 2006.

5. World Health Organization (WHO, 2016): Global Report on Access to Hepatitis C Treatment; World Health Organization: Geneva, Switzerland. Available online: https://apps.who.int/iris/bitstream/handle/10665/250625/WHO-HIV-2016.20-eng. pdf;jsessionid=0DA30F56F3866433F698F2333CFE526F?sequence=1 (accessed on 5 June 2020).

6. Reipold, E.I.; Trianni, A.; Krakower, D.; Ongarello, S.; Roberts, T.; Easterbrook, P.; Denkinger, C. Values, preferences and current hepatitis B and C testing practices in low and middle-income countries: Results of a survey of end users and implementers. BMC Infect. Dis. 2017, 17, 702. [CrossRef]

7. Lim, S.G. HCV management in resource-constrained countries. Hepatol. Int. 2017, 11, 245-254. [CrossRef]

8. Raglow, G.J.; Luby, S.P.; Nabi, N. Therapeutic injections in Pakistan: From the patient's perspective. Trop. Med. Int. Health 2001, 6, 69-75. [CrossRef] [PubMed]

9. Khalid, G.G.; Kyaw, K.W.Y.; Bousquet, C.; Auat, R.; Donchuk, D.; Trickey, A.; Hamid, S.; Qureshi, H.; Mazzeo, V.; Aslam, K.; et al. From risk to care: The hepatitis $\mathrm{C}$ screening and diagnostic cascade in a primary health care clinic in Karachi, Pakistan-A cohort study. Int. Health 2020, 12, 19-27. [CrossRef] [PubMed]

10. World Health Organization (WHO, 2017): Guidelines on Hepatitis B and C Testing; World Health Organization: Geneva, Switzerland. Available online: https:/ / www.who.int/hepatitis/publications/guidelines-hepatitis-c-b-testing/en/ (accessed on 30 May 2020).

11. Shepard, C.W.; Finelli, L.; Alter, M.J. Global epidemiology of hepatitis C virus infection. Lancet Infect. Dis. $2005,5,558-567$. [CrossRef]

12. Serper, M.; Volk, M.L. Current and Future Applications of Telemedicine to Optimize the Delivery of Care in Chronic Liver Disease. Clin. Gastroenterol. Hepatol. 2018, 16, 157-161. [CrossRef]

13. Yoo, E.R.; Perumpail, R.B.; Cholankeril, G.; Jayasekera, C.R.; Ahmed, A. The role of e-health in optimizing task-shifting in the delivery of antiviral therapy for chronic hepatitis C. Telemed. e-Health 2017, 23, 870-873. [CrossRef] 
14. Cooper, C.L.; Hatashita, H.; Corsi, D.J.; Parmar, P.; Corrin, R.; Garber, G. Direct-Acting Antiviral Therapy Outcomes in Canadian Chronic Hepatitis C Telemedicine Patients. Ann. Hepatol. 2017, 16, 874-880. [CrossRef]

15. Rossaro, L.; Aoki, C.; Yuk, J.; Prosser, C.; Goforth, J.; Martinez, F. The Evaluation of Patients with Hepatitis C Living in Rural California via Telemedicine. Telemed. e-Health 2008, 14, 1127-1129. [CrossRef]

16. O'Malley, L. Scoping studies: Towards a methodological framework AU-Arksey, Hilary. Int. J. Soc. Res. Methodol. 2005, 8, 19-32.

17. Levac, D.; Colquhoun, H.; O’Brien, K.K. Scoping studies: Advancing the methodology. Implement. Sci. 2010, 5, 69. [CrossRef] [PubMed]

18. Chen, W.-L.; Chiu, W.-T.; Wu, M.-S.; Hsu, M.-H.; Tsai, S.-H. Translational Research of Telecare for the Treatment of Hepatitis C. BioMed Res. Int. 2014, 2014, 1-6. [CrossRef]

19. Keogh, K.; Clark, P.; Valery, P.C.; McPhail, S.M.; Bradshaw, C.; Day, M.; Smith, A.C. Use of telehealth to treat and manage chronic viral hepatitis in regional Queensland. J. Telemed. Telecare 2016, 22, 459-464. [CrossRef] [PubMed]

20. Rossaro, L.; Torruellas, C.; Dhaliwal, S.; Botros, J.; Clark, G.; Li, C.-S.; Minoletti, M.M. Clinical outcomes of hepatitis C treated with pegylated interferon and ribavirin via telemedicine consultation in Northern California. Dig. Dis. Sci. 2013, 58, 3620-3625. [CrossRef]

21. Lloyd, A.R.; Clegg, J.; Lange, J.; Stevenson, A.; Post, J.J.; Lloyd, D.; Rudge, G.; Boonwaat, L.; Forrest, G.; Douglas, J.; et al. Safety and Effectiveness of a Nurse-Led Outreach Program for Assessment and Treatment of Chronic Hepatitis C in the Custodial Setting. Clin. Infect. Dis. 2013, 56, 1078-1084. [CrossRef]

22. Morey, S.; Hamoodi, A.; Jones, D.; Young, T.; Thompson, C.; Dhuny, J.; Buchanan, E.; Miller, C.; Hewett, M.; Valappil, M.; et al. Increased diagnosis and treatment of hepatitis $\mathrm{C}$ in prison by universal offer of testing and use of telemedicine. J. Viral Hepat. 2019, 26, 101-108. [CrossRef]

23. Mohsen, W.; Chan, P.; Whelan, M.; Glass, A.; Mouton, M.; Young, E.; Tran, Q.; Arora, S.; Davison, S.; Lama, T.; et al. Hepatitis C treatment for difficult to access populations: Can telementoring (as distinct from telemedicine) help? Intern. Med. J. 2018, 49, 351-357. [CrossRef]

24. Beste, L.A.; Glorioso, T.J.; Ho, P.M.; Au, D.H.; Kirsh, S.R.; Todd-Stenberg, J.; Ross, D. Telemedicine specialty support promotes hepatitis C treatment by primary care providers in the Department of Veterans Affairs. Am. J. Med. 2017, 130, 432-438. [CrossRef]

25. You, A.; Kawamoto, J.; Smith, J.P. A pharmacist-managed telemedicine clinic for hepatitis C care: A descriptive analysis. J. Telemed. Telecare 2014, 20, 99-101. [CrossRef]

26. Nazareth, S.; Kontorinis, N.; Muwanwella, N.; Hamilton, A.; Leembruggen, N.; Cheng, W.S. Successful treatment of patients with hepatitis C in rural and remote Western Australia via telehealth. J. Telemed. Telecare 2013, 19, 101-106. [CrossRef]

27. Galán, G.J.; Alia, C.A.; González, M.V.; González, F.F.; Rodríguez, C.M.F.; Fernández, M.G.; García, M.L.G.; Losa, J.E.; Velasco, M.; Moreno, L.; et al. The contribution of telemedicine to hepatitis C elimination in a correctional facility. Revista Española Enfermedades Digestivas 2019, 111, 550-555. [CrossRef]

28. Schulz, T.R.; Kanhutu, K.; Sasadeusz, J.; Watkinson, S.; Biggs, B.-A. Using telehealth to improve access to hepatitis C treatment in the direct-acting antiviral therapy era. J. Telemed. Telecare 2018, 26, 180-185. [CrossRef] [PubMed]

29. Case, L.; Wright, J.; Ryan, Y. Comparison of hepatitis C treatment outcomes between telehepatology and specialty care clinics in the era of direct-acting antivirals. J. Telemed. Telecare 2019. [CrossRef] [PubMed]

30. Arora, S.; Thornton, K.; Murata, G.; Deming, P.; Kalishman, S.; Dion, D.; Qualls, C. Outcomes of hepatitis C treatment by primary care providers. N. Eng. J. Med. 2011. [CrossRef]

31. Kruse, C.S.; Krowski, N.; Rodriguez, B.; Tran, L.; Vela, J.; Brooks, M. Telehealth and patient satisfaction: A systematic review and narrative analysis. BMJ Open 2017, 7, e016242. [CrossRef] [PubMed]

32. De Gijsel, D.; Kruger, B.; Dema Hakim, S.M. (Eds.) Telemedicine for the Treatment of Hepatitis C: A Systematic Review and Meta-Analysis. In Open Forum Infectious Diseases; Oxford University Press: Oxford, UK, 2018.

33. Saifu, H.N.; Asch, S.M.; Goetz, M.B.; Smith, J.P.; Graber, C.J.; Schaberg, D.; Sun, B.C. Evaluation of human immunodeficiency virus and hepatitis $C$ telemedicine clinics. Am. J. Manag. Care 2012, 18, 207-212. [PubMed]

34. Madden, A.; Hopwood, M.; Neale, J.; Treloar, C. Beyond cure: Patient reported outcomes of hepatitis C treatment among people who inject drugs in Australia. Harm Reduct. J. 2018, 15, 42. [CrossRef] [PubMed] 